\title{
HOGYAN VÁLIK A TANÁRKÉPZÉS FOLYAMATA ÁTLÁTHATÓVÁ?
}

\section{PAPp LAJOS}

az ELTE Pedagogikum Központ Oktatásszervezési és Tanulmányi Főosztályának főosztályvezetője

papp.lajos@pk.elte.hu

A tanulmány a tanárképzés rendszerének tervezett átalakítását, az új jogszabályi környezet kialakitási folyamatát mutatja be az „átláthatóság” európai követelményének szempontjából, figyelembe véve az állami-, intézményi- és egyéni szintü megközelítésből adódó elvárásokat, feladatokat és felmerülö problémákat.

Az átláthatóság kifejezés a magyar nyelv értelmező szótáraiból hiányzik, a korai, 19. századiakból éppúgy, mint a 20. század közepén készültekből, de még a legújabból, A magyar nyelv nagyszótárából ${ }^{1}$ is. Tudjuk persze, hogy a szótár szükségszerủen konzervatív, hiszen a szavak, a jelentések gyorsabban változnak, mint ahogy azt a kitünő nyelvtudósok, szótárszerkesztők a szakmai követelményeknek megfelelően leírni tudnák. Ezzel együtt nem vitatható el, hogy a mai magyar nyelvben van egy sajátos jelentéssel bíró szó, az átláthatóság, aminek különös jelentése nem pusztán a szó töve(i) és toldalékai jelentéseinek összege.

Adatolás hiányában csak a személyes benyomások alapján állíthatjuk, hogy az átláthatóság leggyakrabban az európai uniós vagy az ehhez kapcsolódó szakmai tematikájú szövegekben bukkan föl, így a szó jelentését az EU dokumentumaiban érdemes keresni. Az EU honlapján ${ }^{2}$ található szószedet az átláthatóság kifejezést (transparency) két jelentésben tartalmazza: az információkhoz, a dokumentumokhoz való, bárki általi hozzáférés jelentésében (access to documents), valamint az Európai Tanács müködésének, döntési, jogalkotási tevékenységének nyilvánossága jelentésében (transparency of Council proceedings). Az átláthatóság e két jelentésében az európai politika alapvető követelménye. A 2001-ben elfogadott, az európai kormányzásról szóló fehér könyv ${ }^{3}$ deklarálta, hogy az átláthatóság a részvételi demokráciák, illetve a legitim és elszámoltatható közigazgatás müködésének elöfeltétele, majd pedig 2005 novemberében az Európai Bizottság meghirdette az

\footnotetext{
${ }^{1}$ Főszerk.: Ittzés Nóra, MTA Nyelvtudományi Intézet, Budapest, 2006. II. kötet

${ }^{2}$ URL: http://europa.eu/legislation_summaries/glossary Letöltés ideje: 2011. október 21.

${ }^{3}$ European Governance. A White Paper. URL: http://eur-lex.europa.eu/LexUriServ/site/en/com/2001/ com2001_0428en01.pdf Letöltés ideje: 2011. október 21.
} 
európai átláthatósági kezdeményezést, melynek a következményeképpen folyó munkálatok jelenleg is zajlanak ${ }^{4}$.

Az átláthatóság követelményének teljesülése azt teszi lehetővé, hogy az információk elérhetők minden érintett és érdeklődő számára az adott rendszer kialakítása és müködése tekintetében, legyen szó európai politikáról vagy akár magyar felsőoktatásról. Ha egy rövid elemzés keretében megkíséreljük megvizsgálni a felsőoktatás aktuális átalakítási folyamatának átláthatóságát, indokolt ennek különböző szintjeit elkülöníteni. A legáltalánosabb az állami szint, a tanárképzéssel kapcsolatos állami felelősség, az állami szabályozás átláthatósága. A második szint az intézményi szint, a pedagógusképzésben, a tanárképzésben részt vevő felsőoktatási intézmények szintje, ahol az átláthatóság rendkívül fontos mind az intézményi müködés, a változásokra való felkészülés és a változások követése szempontjából, mind pedig a harmadik szint, az egyén szintjének számára, hogy a tizennyolc éves fiatal eligazodhasson, alkalmazkodni tudjon a változási folyamathoz.

\section{Átláthatóság az állami felelősségvállalás szintjén}

A tanárképzéssel kapcsolatos állami felelősségvállalási szinten az átláthatóságnak az európai követelményektől függetlenül is meg kell jelennie, ez több érdekből is kiemelten fontos. Ahogy Államtitkár Asszony a mai konferencián utalt erre, és ahogy az elmúlt hónapok, lassan immár egy év történései is erre intenek, az egyik érdek a nagy rendszerek kapcsolódásának szükségességében jelentkezik. Amikor az állam az oktatási rendszer valamely elemének átalakításába kezd, akkor ennek óhatatlanul hatása lesz minden olyan intézményrendszer müködésére, amelyik az adott tevékenységben érdekelt. A változtatás jellegétől, mértékétől függően persze lehetséges, hogy nemcsak a közvetlenül érintett intézményi kört fogja érinteni, hanem a közvetetten érintetteket is. A tanárképzés megváltoztatása nemcsak a felsőoktatási intézményekre, hanem az egész közoktatás, a szak- és felnőttképzés intézményi rendszerére hatással van. Ez nem az egyes intézmények szintje, hanem az állam müködésének, oktatási filozófiájának, oktatáspolitikájának az átláthatósági szintje. A tanárképzés átalakításának jelenlegi folyamatában kevéssé érzékelhető az említett rendszerek összhangja, a tényleges jogalkotást megelőző, az egyes területekre vonatkozó koncepciótervezeteknek a nyilvánosság számára kevéssé követhető változásai mögött inkább rögtönzések, egyes szakmai vagy érdekcsoportok kívánságai, politikai alkuk állhatnak, semmint egy összeszedett oktatáspolitikai koncepció stabil építökövei. Talán ez a magyarázata annak is, hogy a változtatási elképzelések mögött semmilyen szakmai elemzés nem áll (nem is állhat, hiszen a megváltoztatni szándékozott modell eredményeit még nem ismerhetjük, hiszen még egyetlen ciklusa

\footnotetext{
${ }^{4}$ URL: http://ec.europa.eu/civil_service/admin/transp/index_hu.htm Letöltés ideje: 2011. október 21.
} 
sem zárult le a képzésnek), és rendre szembe mennek a hazai és nemzetközi kutatási eredményeknek, valós oktatási tapasztalatoknak.

Mindannyian tudjuk, hisz a jelenlévők nagy többsége részt vett már korábban ilyen folyamatban, még a hallgatók is, hogy micsoda hatalmasan munka az új képzési rendszerre való átállás. Az állam felelőssége az átláthatóság biztosításában az intézmények irányában rendkívül fontos, hiszen az intézményeknek elő kell készülniük az új tanárképzés bevezetésére, hiszen az oktatási rendszerek váltása hoszszabb felkészülést igényel. A felsőoktatásról szóló, 1993. évi LXXX. tv. elfogadása után négy évig tartott, amíg elkészült a tanári képzés tartalmi követelményeit leíró rendelet (111/1997. /VI. 27./ Korm. rendelet a tanári képesítés követelményeiröl), és további öt évig, mire valamennyi szakmai terület képesítési követelményét kiadta a kormány. A 2005. évi CXXXIX. felsőoktatási törvény esetében az oktatási kormányzat előrelátóbb és rutinosabb volt, a képzési és kimeneti követelményeket alsóbb szintủ ('́gy könnyebben módosítható) jogszabályban, egyetlen miniszteri rendeletben adta ki (15/2006. /IV. 3./ OM rendelet az alap- és mesterképzési szakok képzési és kimeneti követelményeiről), és ennek az előkészületei az alapképzési szakok vonatkozásában - uniós támogatással, a Humánerőforrás-fejlesztési Operatív Program támogatásával - már évekkel a törvény elfogadása előtt elindultak. A tanári mesterszak kkk-ja azonban így is csak két évvel későbben, 2007-ben készült el, és csak az általános rész, valamint a hittanár-nevelö tanár [!] és a mérnöktanár szakképzettségé. Újabb két év telt el, míg a tanári szak valamennyi szakképzettségéhez sikerült kiadni a rendelet kiegészítését, s csak ezt követően indíthatták, utoljára a mủvésztanárképzésben az intézmények az indítással kapcsolatos akkreditációs eljárásokat. Igaz, a mesterszakos képzés a hároméves alapképzést követte, így az új képzési rendben lényegében ,időre” elkészült három év alatt a kkk-k többsége. (Más kérdés, hogy az intézményi tantervek is készen voltak-e valamennyi modulméret és félévszám vonatkozásában az akkreditációra, hiszen ezt a MAB az akkreditációs eljárásban egyáltalán nem vizsgálta.)

Az intézményi felkészülés azonban nemcsak a képzés tartalmának megváltoztatásához, hanem az adekvát szervezeti keretek kialakításához is szükséges. Ilyen például a tanárképző központok (korábbi koncepció-tervezetekben tanárképző intézetek) kérdése is, ami hónapról hónapra új változatban jelent meg a törvénykoncepciók egyes változataiban. Kétségtelen, hogy e kérdésben az állami érdek megjelenítése indokolt. A közoktatás ugyanis vitathatatlanul állami feladat, tehát az oktatás főszereplői, a tanárok képzésében is meg kell jelennie az állami érdek képviseletének. Az állam láthatóan erősebben kívánja kontrollálni a tanárképzés folyamatát, jogos tehát, hogy az intézményi szervezeti kereteket is átláthatóvá kívánja tenni. Az azonban nem mellékes, hogy mindez milyen intézményi struktúra kialakításával jár, kari funkciójú, oktatási szervezeti egység létrehozásával vagy egy koordináló funkciójú, hivatali szervezetével, vagy úgy, ahogy az intézmény akarja, akár egy néhány fös testületi forma megteremtésével. Nem világos egyelöre 
az oktatáspolitika álláspontja az intézményi autonómia és az állami érdek érvényesítésének viszonyában. Ha viszont nem átlátható a kormányzati szándék, akkor rendkívül nehéz helyzetbe kerülnek az intézmények, hiszen nincs módjuk időben rákészülni. Ebben az esetben is csak a jogszabály fokozatos hatályba léptetése lehet a megoldás.

Ha nem elég világos, nem eléggé átlátható, hogy mit is kíván az oktatási kormányzat a tanárképzés kapcsán megjeleníteni, mi a változtatási szándék, akkor bármilyen szakmai terv elfogadtatása a kormányzaton belül is nagyon nehéz. A Kormányban különböző szakmai és általánosabb érdekek jelennek meg. Ahogy régen is, ma is ütköznek a szakmai és a financiális szempontok (Klebelsberg Kunó ez irányú küzdelmeiröl Mikonya Györgytöl hallottunk éppen a mai napon, de ugyanezt élte meg Eötvös Józseftől kezdve minden oktatással foglalkozó miniszter a maga korában). Ha világosan, egyértelmúen nem fogalmazódnak meg a szakmai, szakmapolitikai célok, akkor a változtatásokhoz forrásokat nehéz biztosítani, különösen mostanában, gazdasági válság idején. Már tavaly augusztusban megfogalmazódott az az elképzelés, hogy a tanárképzésben a szakmai gyakorlat időtartama kétszeresére növekedjék. Egy ilyen - egyébként szakmailag vélhetően helyes - szándék keresztülvitele, a többletforrások biztosítása nehezen érhető el, ha nem világos az a szándék, ami ezt motiválja, ha a képzés egész struktúrájának átalakításában folyamatos változtatgatások jelentkeznek, melynek legutóbbi licitje az 5+1 és 4+1 éves változatot tartalmazza. Ha az oktatáspolitikai szándék átláthatóságának hiánya elbizonytalanítja a döntéshozatali folyamatot, akkor az könnyen oda vezethet, hogy elvész a jelenlegi, 5 és fél éves, Európában - ahogy ez Stéger Csilla előadásából is kiderült egyedülállóan hosszú képzési időtartam, így a különben jó szándékú kezdeményezés visszájára fordulhat, és a tanárképzés kereteinek változtatásával azok szükítését eredményezheti.

Az átláthatóság állami szintjének része a jogszabályi koherencia is. Jelenleg az oktatási kormányzat a kapcsolódó rendszerek szinte mindegyikében alapvető tartalmi és működési változtatásokat tervez, azonban a rendszerek összhangja az erre irányuló törekvések ellenére sem egyértelmü. Ha például a tanárképzésben a tervek szerint megnő a szakmai gyakorlat időtartama, és ezzel egyidejüleg a gyakorlaton részt vevők számára kötelezően fizetést adat a törvény a gyakorlóhellyel, ez olyan többletkiadást jelent a közoktatási intézményrendszerben, amire ott forrás biztosítása a jelen finanszírozási keretek között lehetetlen.

A felsőoktatás valamennyi résztvevője tapasztalta, hogy milyen nehéz annak a szétzilált jogszabályi háttérnek a követése, a jogszabályok közötti eligazodás, ami a 2005-2006-os jogszabályalkotás során kialakult. A teljesen új jogszabályi környezetben, amit a jelenlegi kormányzat tervez, több tucat kapcsolódó jogszabály elkészítése szükséges a koncepció különböző változatai szerint is. Aki valaha kodifikációs tevékenységet közelről látott, az tudja, hogy milyen aprólékos munkát igényel ezeknek a jogszabályi hierarchiába tartozó elemeknek a létrehozása úgy, 
hogy az elemek illeszkedjenek egymáshoz, hogy a rendszer müködőképes legyen. Azzal, hogy egy koncepciót vagy egy jól-rosszul megcsinált törvényt elfogadunk, még nem lesz átlátható és müködőképes a rendszer. Minél mélyrehatóbb törvényi változások következnek, annál több idő és szakértelem szükséges az átlátható új jogszabályi környezet kialakításához.

\section{Az átláthatóság igényének értelmezése a felsőoktatási intézmény szintjén}

Mi a legfontosabb teendőjük a felsőoktatási intézményeknek, ha az új tanárképzés átláthatóságát meg kívánják teremteni? Az összetett jogszabályi környezethez igazodva ki kell alakítani a saját intézményi szabályozásukat. Az intézményi szabályozásnak is több rétege van, hiszen a tartalmi, tantervi szabályozás mellett ide tartozik a különböző müködési szabályok megalkotásának szüksége és a már említett, szervezeti szabályozás is.

Megnyugvással hallhattuk Államtitkár Asszonytól azt a hírt, hogy a tanárképzéssel kapcsolatban nem ebben az évben tervezi a változások bevezetését az oktatási kormányzat, hanem csak jövőre. Az ELTE-n egyelöre - legalábbis a jelenlegi statisztikai adataink alapján - lesznek még olyan tanárképzésben részt vevő hallgatók, akik a kreditrendszer előtti képzésben vesznek részt, és teljesen jogszerüen, hiszen az 1993. évi Ftv. keretei közötti kihagyással, teljesen szabályosan végezhették és végzik a tanulmányaikat. Lesznek kreditrendszerü képzésben részt vevő, a 111/1997. sz. Korm. rendelet szerinti képesítési követelmények alapján tanulók, és lesznek természetesen az új, a 2005. évi Ftv. szerinti, bolognai rendszerü tanári képzésben részt vevők is. Mivel a 2012. évi felvételi eljárásban még bizonyosan bekerülnek felvételizők a jelenlegi tanári mesterszakra, az ő képzésük legalább 2015-ig, a jogszabályokban biztosított kihagyásokkal élve akár évekkel tovább is folyhat. Az új szabályozással megjelennek majd a most kialakuló, új rendszerü képzésben részt vevők is. Az intézményi szabályozást a párhuzamosan folyó, többféle tanárképzésre úgy kell kialakítani, hogy gazdaságosan lehessen bánni az erőforrásokkal, hogy a különböző képzések közötti átjárhatóságot biztosítsa, és hogy mindenki, hallgató, oktató és hivatal egyaránt egyértelmüen tudjon eligazodni benne. Mindennek az átláthatóságát biztosítani rendkívül nemes feladat lesz az intézmények számára, divatos szóval élve izgalmas kihívás.

Az ELTE elektronikus tanulmányi rendszere már ma is küszködik a többféle tanárképzési modellel. Csak a jelenlegi, bologna rendszerü képzésnek van a rendszerben kezelhető formája, az összes többi korábbi rendszerü tanári képzésnek azonban nincs. Igaz, az ELTE által használt rendszer az ETR-nek egy igen korai változata, aminek használatát nehezíti a tanárképzésben részt vevő karok nagyon eltérő gyakorlata is. Az ELTE a tanári képzés változásaihoz igazította folyamatosan a szervezeti kereteket is: a jelenlegi, egységes tanári mesterszaknak értelemszerủen egyetlen szakgazdája van az egyetemen, a Pedagógiai és Pszichológiai Kar. 
Nagy kérdés, hogy az egységes szak újbóli szétválasztása számos önálló tanárszakra milyen szervezeti változásokat indukál, s ezek milyen szabályozási-müködési különbségeket eredményeznek az egyes karokon.

Többször elhangzott a közelmúltban, elsősorban minisztériumi föosztályvezető-helyettesi tájékoztatókban, ha lesz új tanárképzési modell, akkor nem kell majd újból akkreditálni ezeket az új tanárszakokat, hiszen ahol folyik a jelenlegi öt és féléves tanárszakon képzés, ott majd lehet azt „folytatni” a tíz vagy a tizenkét féléves új tanárszakokon is. Látható azonban egy érdekes ellentmondás és egyben kockázat is ebben a megoldásban. Ha a jelen oktatáspolitikai szemlélet szerint az államnak eminens érdeke, hogy mint megrendelő meghatározza a tanárképzés tartalmi, képzésszerkezeti, esetleg szervezeti kereteit, akkor ez az igény nehezen érvényesülhet a tantervi szabályozás egyedi intézményi modelljében. Vajon hogyan viszonyul majd az országban a húszegynéhány tanárképző hely az egységes tartalom implicit elvárásához? Vajon hányféle tanterv készülhet egy olyan intézményi körben, ahol sokhelyütt - elsősorban a természettudományos tanárképzésben - a 15/2006-os OM rendelet elöírásait, de még a 111/2007-es kormányrendeletéit sem hajtották végre? Abban a közegben, ahol öt év alatt még terminológiai szinten sem sikerült a „tanárszakok” vs ,tanári mesterszak” megkülönböztetést elsajátítani, ahol a megszokásnak hódolva a 30/40/50 kredites szakterületi modulokat nevezik ma is ,szak”nak. A jelenlegi, rendkívül tagolt, moduláris rendszerü, 180+150, 300+60/90, $330+60 / 90,240+60 / 90$ stb. kredites, különbözö belső moduláris szerkezetü képzésekböl hogyan lesz érdemi változtatások nélkül egységes 300 vagy 360 kredites képzés? A felsőoktatási intézmények nem ússzák meg, új tanterveket kell csinálni, olyanokat, amik az osztott és osztatlan képzések, illetőleg a diszciplináris és a tanári szakok oda-vissza átjárhatóságát, az egy- és többszakosság lehetőségét is biztosítják. A tanárképzés intézményi szintủ átláthatóságát csak így lehet megteremteni. Vajon egy ilyen volumenủ tartalmi átalakításban miként fog érvényesülni a tartalom és a képzés színvonalának egységességére irányuló kormányzati szándék az akkreditáció minimális ellenőrzési funkciója nélkül?

\section{Az átláthatóság fontossága az egyéni döntések szempontjából}

És hát nem elhanyagolható az átláthatóság igénye az egyén, a pályát választó, tizennyolc éves és az ő tanulmányait lehetővé tevő családja számára sem. Az egyéni életút tervezéséhez feltétlenül szükséges, hogy lássuk azt, milyen lesz a pedagóguspálya perspektívája. Ha a pedagógus életpálya-modell tervei alapján ma csak annyit tudunk mondani, hogy a jövőben majd lesz valamilyen fejlesztés a pedagóguspályán, hogy valamennyire majd bizonyosan emelkednek a jövedelmek, de nem tudjuk, hogy mennyi munka vár a tanárra, nem tudjuk, hogy a tanításon kívüli iskolai adminisztratív tevékenységekben kap-e segítséget a tanár valamilyen pedagógiai asszisztencia keretében - ahogy az a világban számos helyen megvalósulva lehető- 
vé teszi a nagyobb óraszámban való tanítást -, ha radikálisan nem nő a pedagóguspálya presztízse, akkor sajnos nem lesz több tehetséges és elkötelezett, tizennyolc éves fiatal, aki a tanári pályát választja. Az egyénnek terveznie kell előre, látnia kell, hogy mire vállalkozik. Kevés pénzért sok munka, csökkenő gyereklétszám, iskolabezárások, egyre konfliktusosabb nevelési helyzetek, ezek nem a legcsábítóbb jellemzői a pedagóguspályának, de ma ezek a legismertebbek.

A piaci viszonyok érvényesítése az oktatásban a jelenlegi kormányzat számára nem elfogadható modell. Ez önmagában nem kifogásolható, többféle megközelítésmóddal is el lehet ugyanazt az eredményt érni, egy kiegyenlített színvonalon, átláthatóan, tervezhető keretek között müködő oktatási rendszert. Az egyén azonban mindig piaci, jelesül munkaerö-piaci szempontok figyelembevételével alakítja az életútját, még akkor is, ha ezt így nem fogalmazza meg magának, s ha az ismeretei csak nagyon vázlatosak. Olyan szakmát, olyan intézményt keres, amivel, amelyik diplomájával vélhetően jól (fizető állásban) tud majd elhelyezkedni. A felsőoktatás bolognai átalakítása látványosan megmutatta, hogy a tanári pálya nem ilyen. A tanári mesterszak iránti szerényebb érdeklődést elsősorban az magyarázza, hogy a mesterszakok bőséges kínálata között a többség talált olyan szakot mind a bölcsész, mind a természettudományos területen, amivel, úgy vélte, jobb álláshoz jut, mint ha a tanári szakot végezné el. Miért menjen a tehetséges fiatal matematikatanárnak, ha matematikusként a vállalati-banki szektorban összehasonlíthatatlanul jobb feltételekkel talál munkát?

A tanárképzésre a jelen munkaerő-piaci feltételek között csak akkor lesz megfelelő számú jelentkező, ha a nem tanári szakok kapacitását korlátozzák az intézmények vagy maga az állam, és így a több évtizede jól bevált kontraszelekcióval sikerül a kevésbé tehetséges fiatalokat erre az útra terelni. Biztosítani kell persze - például kötelező elhelyezkedés előírásával vagy a képzési költség visszafizetésének fenyegetésével - azt is, hogy a tanári végzettségü friss diplomások akkor is tanárként helyezkedjenek el, ha találnának jobb állást is maguknak az egyetem vagy a föiskola után. Ilyen sajátos kényszerítő eszközök hiányában ugyanis az egyén az átlátható vagy csak enyhén áttetsző piaci viszonyok között vélhetően a saját érdekei szerint fog dönteni.

Az egyén szempontjából az átláthatóság másik fontos szerepe az esélyegyenlősséggel függ össze. Az egyéni esélyegyenlőség szempontjából is kétféleképpen szükséges az átláthatóság biztosítása, az egyén mint a felsőoktatásba igyekvő személy és az egyén mint a felsőoktatásból diplomával elhelyezkedni szándékozó személy számára - a két szempont sajátosan erősíti egymást. Mára sajnos már közhelyes megállapítás, hogy Magyarországon az egyéni életutat a legmagasabb iskolai végzettség és a társadalmi mobilitás szempontjából alapvetően határozza meg az, hogy ki hova születik, miként az is, hogy az esélyek kiegyenlítésében az iskolának van elsődleges feladata. Ugyanez igaz a felsőoktatási szak- és intézményválasztásban is. Hosszabb ideje általánosan érvényesülő sajátosság, hogy az intézmény- 
választásban éppúgy, mint az elhelyezkedésben a lakóhelyhez való közelség fontos szerepet játszik. Sokat kell még tennie azért a felsőoktatásnak és az államnak is, hogy országosan egyenszilárdságú legyen a tanárképzés mind a pedagógiai felkészítés, mind a szakterületek száma, mind a képzési színvonal tekintetében, de enélkül bizonyosan nem érhető el az, hogy az országban mindenhol legyen elegendő számban és szakterületi megoszlásban a kívánt színvonalon kiképzett tanár.

A pedagógusképzés és a közoktatás összekapcsolódásának az esélyegyenlőséget meghatározó, fontos jellemzője az, hogy vajon az adott régió, településtípus számára képez-e megfelelő számú és megfelelő pedagógust a felsőoktatás, aminek viszont egyértelmü eredménye, hogy jelentkezik-e a pedagógusképzésbe az adott régióból, településtípusból elegendő számban tehetséges fiatal. Ördögi kör ez, amiből kitörni csak alapos elemzéseken nyugvó, az oktatási alrendszereket egységben látó és kezelö, a szükséges forrásokat is biztosító, az európai és a hazai pedagógiai-szakmai követelményeket és tapasztalatokat figyelembe vevö, a rövidlátó politikai és lobbi érdekeket nélkülöző és nem utolsósorban átlátható oktatáspolitikával lehet. Hic Rhodus, hic salta! 